\title{
The Effect of Chewing Sugar Cane on Plaque Formation
}

\author{
$1^{\text {st }}$ Naning Nur Handayatun \\ Dental Nursing Department \\ Polteknik Kesehatan Kemenkes Jambi \\ Jambi, Indonesia \\ ningfendi2@yahoo.co.id
}

\author{
$2^{\text {nd }}$ David Rudi \\ Dental Nursing Department \\ Polteknik Kesehatan Kemenkes Jambi \\ Jambi, Indonesia \\ david.jkg123@gmail.com
}

\author{
$3^{\text {rd }}$ Karin Tika Fitria \\ Dental Nursing Department \\ Polteknik Kesehatan Kemenkes Jambi \\ Jambi, Indonesia \\ karin.tikafatria@gmail.com
}

Corresponding author: ningfendi2@yahoo.co.id

\begin{abstract}
Plaque is a non-calcified deposit that coating the teeth and consist of $70 \%$ microbial with the presence of sugar. Plaque coulddevelop into dental caries. Sugar cane has been used for centuries due to its high content of sucrose and nutrition. People nowadays still consuming it raw by chewing. This study aims to determine the differences in plaque formation after chewing sugar cane. This is a quasi- experimental with 30 caries-free respondents as a control and treatment group. Respondent brushed their teeth toset the plaque score that measured with PHP-M index to O(which called pretest). The respondent then chewed the sugar cane for32 times. Plaque score was examined 5 minutes and 30 minutes after the chewing process is done. The independent t-test was performed to compare the plaque score recorded after chewing sugar canewith the control group plaque score.The results showed that for 5 minutes after chewing the sugar cane the average examined plaque score is $\mathbf{1 5 . 8 3}$ and the control is 17.43. On the examination of 30 minutes after consuming sugar cane, the average plaque score is $\mathbf{1 9 . 3 7}$ and the control is 21.73 . Independent t-test showed that significant differences were found at the pre-test, 5 minutes after chewing sugar cane, 30 minutes after chewing sugar cane, and the control group $(\mathbf{p}<5)$.At 5 minutes and 30 minutes after chewingsugar cane, the plaque scoreis lower but no significant differences control group were found $(p>0,05)$. It could be concluded that chewing sugar cane could reduce the build-up of plaque but notstatistically significant.
\end{abstract}

Keywords: sugar cane, dental plaque, chewing.

\section{INTRODUCTION}

Plaque is a non-calcified soft deposit which attached to the teeth and other parts of the oral cavity such as dental fillings, dentures, and tartar. Plaque consists of $70 \%$ microbial and the other $30 \%$ is glycoproteins, carbohydrates, and fats. The main organic components of plaque are calcium, phosphorus and magnesium, potassium, and sodium [1]. Plaque is a cause of periodontal disease [1]. and dental cavities [2]. The dental plaque is very easy to form 5 minutes after a proper and clean brushing. Plaque already could be seen with the help of disclosing solution from food coloring [3].

Sugar cane is one of the common plants that can be easily found in Indonesia. Sugar cane is cultivated as a basic ingredient in sugar production. Moreover, Sugar cane also could be seen to be planted in the yard to be consumed daily as a snack food. Sugar cane has many benefits for the body, but sucrose is a cariogenic food which will cause cavities. The sucrose content in 100 grams of sugar cane is $5-21 \%$.

The plant systematics or taxonomy of sugar cane according to [4]. are: a) Division: Spermatophyta, b) Subdivisions: Angiospermae, Monocotylae Class, c) Order: Graminales, d) Family: Graminae, e) Genus: Saccharum, f) Species: Saccharum officinarum. The composition of sugar cane stem consists of $0.5 \%$ $1.5 \%$ monosaccharide, $11 \%-19 \%$ sucrose, $0.5-1.5 \%$ ash organic matter, $11 \%-19 \%$ coir (cellulose pentosan), $0,15 \%$ organic acid, wax materials, colour pigments, and $65 \%-75 \%$ water.

Sugar cane belongs to the Graminae (grasses) family and the genus is Saccharum. Saccharum officinarum is the most widely cultivated sugar cane type and selected by farmers because of its excellent quality for making sugar. Sugar cane plants can grow in high and moderate climates at temperatures around $22-27^{\circ} \mathrm{C}$ with a spread area between $35^{\circ} \mathrm{LS}$ and $39^{\circ} \mathrm{LU}$ (Sudiatsa, 1984) [5]. 
Consumption of sugar cane by chewing can reduce the debris index on elementary school students in Palimanan [6]. However, in contrast to plaque, debris could disappear just by rinsing the mouth, while the plaque is firmly attached to the surface of the teeth. Research in India found that chewing raw sugar cane affected the decreased caries experience in 12 years old children [7]. However, with the high sugar content in sugar cane, further investigation about the effect of sugar cane mastication on plaque formation is needed.

\section{METHODS}

This research is a true experimental research. The experimental design was the Pre and Post Test Control Group Design. The study was conducted at the Dental Care Clinic of the Dental Nursing Polytechnic of Jambi in June 2017. The sample was 30 students of the Dental Nursing Department, Jambi Health Polytechnic of Health Ministry. The sampling technique was carried out by simple random sampling from participants who met the inclusion criteria.

Inclusion criteria: caries-free sample or email caries that do not need clogging yet, no tartar, healthy periodontal tissue, and has no drug and food allergies. The students are voluntarily willing to be a respondent, evidenced by filling out the inform consent. The index teeth are $46,41,36,26,31$, and 16 .

Exclusion criteria: heavy crammed teeth, tartar, caries, hypersensitivity, allergic to drugs and food, and unwilling to be respondents. This research has obtained Ethics Clearance from Jambi University's Ethics Commission.

\section{A. Experimental Method}

To equate the respondent's mouth condition, the respondents were prohibited to eat after $10 \mathrm{PM}$ and instructed to brush their teeth until the plaque score becomes 0 . Respondents should only drink water until the experiment begins at 7 AM. A disclosing applied to the respondents before they were instructed to brush their teeth cleanly until the plaque score becomes 0 .

The treatment group was chewing $2 \mathrm{~g}$ of sugar cane until it runs out of the juice. Sugar cane was chewed 32 times on the left and right teeth. The respondents are not allowed to eat and drink after chewing the sugar cane. After 5 minutes and 30 minutes, the plaque score was checked. In the control group, respondents brushed their teeth until the plaque score was 0 . Afterwards, the plaque score for 5 minutes and 30 minutes after cleaning were examined

\section{B. Plaque Assessment Method}

The respondent was sit on the dental unit when the plaque examination is carried out. The plaque was checked visually with the support of clear illumination from $30 \mathrm{~cm}$ distance. The plaque was assessed by 3 observers. The examined teeth were smeared with the disclosing solution from food coloring [8]. The plaque that sticks to the index teeth (i.e. 16, 21.36 and 26.11, 16) was checked. It was scored 1 if the red covered $1 / 3$ of the cervical tooth surface, scored 2 if the red covered $1 / 3$ to $2 / 3$ of the tooth surface, and scored 3 if the red colour covered $2 / 3$ incisal or occlusal of buccal or labial surfaces. The total score of plaque is summed up and the average is calculated.

\section{RESULTS AND DISCUSSION}

Figure 1 shows the result of the examination that carried out on the respondents. Figure 1 shows that 5 minutes after the respondents brushed their teeth cleanly (plaque score $=0$ ), the plaque score was significantly increased in both the sample and control group. However, the average of plaque scoreincrements in the group that chewed sugar cane was lower than the control group. The same result also found on examination after 30 minutes. The plaque formation was more extensive in the control group than in the sample group. The normality test result showed that the control and sample group were homogeneous. The ANOVA test results for the overall average examination was $\operatorname{sig}=000(p<0.05)$.

Figure 1. PHPM Score on Control Group and Control Group

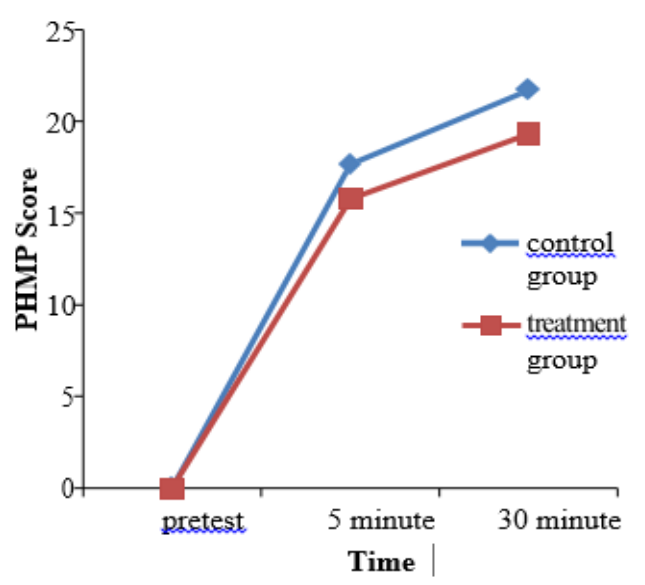


Table 1. ANOVA Statistical Test Results of PHP-M Examination in Pre-test Respondents, After 5 Minutes, and After 30 Minutes in The Sample and Control Group

\begin{tabular}{cc} 
Pretest & Average \\
Treatment Group & 0 \\
\hline 5, & 15,83 \\
Treatmet Group 30' & 19,37 \\
\hline Control group 5' & 17,43 \\
\hline Control group 30' & 21,73
\end{tabular}

Anova

0,000

Furthermore, paired t-test was performed on control group and the result can be seen in table 2.It could be seen from table 2 that sig< $<0.05$ in the paired t-test pretest (score 0 ) with after 5 minutes brushing, in pre-test with 30 minutes, and examinations after 5 minutes with 30 minutes. It could be concluded that Ho is rejected, so there are significant differences in all plaque score examination pair. Furthermore, there was a significant plaque formation on 5 minutes and 30 minutes examination after respondents brushed their teeth. Plaque formation increased with the increment of time, both in the control group who did not do the intervention and in the sample group that was chewing sugar cane. This is following the results of [9]. research which conclude that the plaque was re-formed at the 5 minutes examination after brushing teeth cleanly (plaque score $=0$ ).

Table 2. Paired T-Test on Treatment Group and Control Group

\begin{tabular}{lll}
\hline PHPM-Score & $\begin{array}{c}\text { Treatment } \\
\text { Group }\end{array}$ & $\begin{array}{c}\text { Control } \\
\text { Group }\end{array}$ \\
\cline { 2 - 3 } & \multicolumn{1}{c}{ Sig } & \multicolumn{1}{c}{ Sig } \\
\hline Pretest $\times 5{ }^{\prime}$, & 0,000 & 000 \\
\hline Pretest $\times$ 30, & 0,000 & 000 \\
\hline $5{ }^{\prime} \times 30$, & 0,037 & 0,033 \\
\hline
\end{tabular}

Table 2 showed the paired of t-test performed on treatment group and control group. There was a significant difference between the plaque score of teeth before chewing the sugar cane and 5 minutes and 30 minutes after chewing the sugar cane (sig. <0.05). There was no significant difference between the plaque score between the 5 minutes and 30 minutes after chewing (sig.> 0.05). It could be concluded that after consuming sugar cane, there was a significant increase in the number of plaques compared to before consuming sugar cane.
The average plaque score at the 5 minutes examination after brushing teeth in the control group was greater. The statistical test with the independent t-test results between the sample and control groups showed that there were no significant differences between the sample and control groups at the 5 minutes and 30 minutes examination ( $p>0.05)$. This result shows that even though in the treatment group the average PHPM score is higher but it is statistically not significant.

Table 3. Independent T-Test Results of Average PHPM Score on Treatment and Control Group

\begin{tabular}{cc} 
& Sig \\
\hline Pretest $\times$ 5' & 000 \\
\hline Pretestx 30' & 000 \\
\hline $5^{\prime} \times$ x 30' & 0,033 \\
\hline
\end{tabular}

It could be concluded that consuming sugar cane by chewing causes less plaque build-up than the untreated condition. However, this is statistically insignificant so that the formation of plaque when chewing sugar cane is the same as the untreated condition. Besides, after 5 minutes and 30 minutes consumption of sugar cane, there was a significant decrement in plaque formation (Table 3). This is possibly occurred due to the chewing activity which induced self-cleansing. Although sugar cane contains sugar, the chewing activity could stimulate the salivary glands to secrete more saliva. The saliva will be thinner and will reduce the sweetness level of the sugar cane. Furthermore, the number of carbohydrates that attached to the teeth, which are food for bacteria, is decreased.

This study also supported by [10]. that chewing strawberries and apple can reduce the risk of plaque accumulation.

Chewing gum ingredient sucrose and xylitol also capable descrease plaque formation [11]. [12]. showed that chewing gum reduces dental plaque, increases saliva flow and reinforces saliva buffer capacity; Activity of chewing gum dan chewing sugar cane can clean up any debris on dental surface and can increase saliva production which is can clean the oral cavity.

\section{CONCLUSION}

The results of the study showed that after consuming sugar cane by chewing, the formation of dental plaque did not differ from the control group who did not consume anything after brushing teeth. Sucrose in sugar cane have no effect on plaque formation when consumed by chewing.

\section{ACKNOWLEDGEMENTS}

Thank you to the research respondents and funders who participated in this research. 


\section{REFERENCES}

[1] Fedi P., Vernino A., Gray JL. Silabus Periodonti. Jakarta: EGC; 2005.

[2] Houwink et al. Ilmu Kedokteran Gigi Pencegahan. Yogyakarta; Yogyakarta: Gadjah Mada University Press.; 2000.

[3] Valentina, NK, Handayatun N. Efektivitas Pasta Gigi yang tersedia di Pasaran di Kota Jambi. Jurnal Poltekkes Jambi 2010;10.

[4] Yuwono,S.,S. No Title n.d.

[5] Marliani P V. 2011, Analisis Kandungan Hara N dan P Serta Klorofil Tebu Transgenik IPB 1 yang di Tanam di Kebun Percobaan PG Djatiroto Jawa Timur, Skripsi,. Bogor: 2011.

[6] Nugroho C. Efek Konsumsi Jajanan Tebu Batang Terhadap Kebersihan Gigi Dan Mulut Pada Siswa-Siswi Kelas V Sdn 3 Palimanan Timur Kecamatan Palimanan Kabupaten Cirebon. Indonesian Oral Healh Journal 2017;2:1-8.

[7] Singh, A.; Grover, H.; Bhatia HP. The Study of Cariogenicity of Raw Sugarcane in 12-year-old Children in Punjab, India. Journal of Oral Health \& Community Dentistry Vol 7 Issue 1, P37-43 7p n.d.;7:37-43.

[8] Kayo N, Handayatun N., Mudehir M. Efektifitas Berbagai Macam Sumba Sebagai Bahan Pengganti Disclosing Solution Untuk Mewarnai Plak Gigi. Jurnal Poltekkes Jambi 2012.

[9] Kayo, V.N, Handayatun, N. N, Mudehir. M. Efektifitas Berbagai Macam Sumba Sebagai Bahan Pengganti Discosing Solution untuk Mendeteksi Pak di Dalam Mulut. Jurnal Poltekkes Jambi 2012;6.

[10] Koagouw MS, Mintjelungan CN, Pangemanan DHC. Perbandingan Indeks Plak Gigi Setelah Mengunyah Buah Stroberi dan Buah Apel Pada Siswa SMK Negeri 6 Manado. E- GIGI 2016;4. https://doi.org/10.35790/eg.4.2.2016.14160.

[11] Lies WS dan E. Pengaruh pengunyahan permen karet yang mengandung sukrosa dan permen karet yang mengandung xylitol terhadap indeks plak gigi. J Keperawatan 2011;XIII:1- 5.

[12] Chicles E De, Salival F. Effect of Xylitol Chewing Gum on Dental Plaque, Sali- va Flow and Saliva Buffer Capacity in Chilean Youngsters 2013;7:133-7. 